Prof. Aleksandar Mojašević, ${ }^{*}$ LL.D.

Associate Professor,

Faculty of Law, University of Niš

Stefan Stefanović, ${ }^{*}$

PhD Student,

Faculty of Law, University of Niš

UDK: 339.137:346.546

$327(410) " 20 "$

Рад примљен: 19.05.2021.

Рад прихваћен: 14.06.2021.

\title{
CONSEQUENCES OF BREXIT ON THE COMPETITION LAW AND POLICY OF THE UNITED KINGDOM AND THE EUROPEAN UNION**
}

\begin{abstract}
The subject matter of this paper are the short-term and longterm consequences of Brexit, a historical event and a turning point in the development of the European Union (EU), as well as for the United Kingdom (UK) and the EU competition law and policy. The article first provides a comparative analysis of the historical development of legal regulation of competition in the $U K$ and the EU, including relevant cases from the practice of competition authorities. In particular, the authors focus on the decisions of the European Commission regarding anti-cartel policy. The article further examines to what extent Brexit will influence the mergers and acquisitions policy, anti-trust policy, anti-cartel policy, and state aid policy in the UK and the EU. The central question refers to the extent of Brexit's influence on the change of the UK and the EU business environment, and the repercussions that this change will have for the competition law. In the concluding remarks, the authors discuss the direction offuture development of the UK competition law, particularly in terms of whether and to what extent the UK law will be harmonized with the EU competition law and case law in this area, or whether there will be a radical turn towards adopting a completely new concept of competition law and policy.
\end{abstract}

Keywords: Brexit, UK competition law, EU competition law, short-term consequences, long-term consequences.

\footnotetext{
*mojasevic@prafak.ni.ac.rs

*sstefanovic1991@gmail.com

${ }^{* *}$ This article is the result of research within the program funded by the Ministry of Education, Science and Technological Development of the Republic of Serbia (contract number 451-0368/2020-14/200120).

${ }^{* *}$ The paper was presented at the International Scientific Conference "Law and Digitalization", held at the Faculty of Law, University in Niš, Serbia, 23-24 ${ }^{\text {th }}$ April 2021.
} 


\section{Introduction}

The European Union (EU), as a product of aspirations of European nations to build the European community and the unique European values in the period after World War II, undoubtedly represents the largest project on the European soil in the $20^{\text {th }}$ century. France, West Germany, Italy, the Netherlands, Belgium, and Luxembourg signed the Treaty establishing the European Economic Community in Rome on 25 March 1957, ${ }^{1}$ thus creating a single market and a customs union. The institutional foundations of modern EU competition law can be found in this Treaty, given that the basic provisions referred to the free movement of goods, reduction of customs duties between member states, and abolition of monopolies. The gradual recovery of the economies of European countries in the decades after the World War II devastations, accompanied by the process of their political rapprochement, indicated tectonic changes of the geopolitical map of Europe. A key step in the process of creating a united Europe was taken on 7 February 1992, by signing the Maastricht Treaty (Treaty on the European Union), which entered into force on 1 November 1993. This document has firmly established economic and social cohesion, as one of the basic goals of the European Union, along with the single market and the Economic and Monetary Union. ${ }^{2}$

A well-designed and consistently implemented competition policy is one of today's pillars of the functioning of the single European market. Competition policy is not an end in itself but one of the main instruments of economic policy, whose ultimate goal is the creation and proper functioning of the single market. The challenge of creating a single market was all the greater because each of the EU member states has its legal system. Economic policymakers have realized that only the establishment of a single legal framework for business entities could lead to the smooth functioning of a free market economy. The purpose of competition policy, as an integrative factor of aspirations to a single market, is to prevent undesirable behaviors of companies, whose ultimate goal is to distort free competition. If we take the economy of just one country as an example, regardless of which legal system it belongs to, it is clear that developed competition is of great importance for the economic development of the country itself and for all economic entities operating on its market. Unified competition policy and competition law are very important for the EU economy, given the

1 Encyclopedia Britannica: Treaty of Rome. Retrieved 13.2.2021 from https://www. britannica.com/event/Treaty-of-Rome

2 European Commission. The Maastricht Treaty: an impetus for the cohesion policy. Retrieved 9.2.2021 from https://ec.europa.eu/regional_policy/en/newsroom/news/2016/12/12-092016-the-maastricht-treaty-an-impetus-for-the-cohesion-policy\#: :text=The $\% 20$ treaty $\% 20$ brought $\% 20$ the $\% 20$ first,the $\% 20$ Economic\%20and\%20Monetary\%20Union. 
specificities of the legal systems of member states and the uneven level of their economic development (Cseres, 2010: 8).

A historical event that will have long-lasting consequences on the future of the EU is certainly Brexit, the withdrawal of the United Kingdom (UK) from the EU. Competition law and competition policy are fields where Brexit will have major consequences, both on the UK and the EU. Therefore, this paper first provides a comparative analysis of the historical development of the legislative framework of the UK and the EU. The central part of the paper focuses on the analysis of short-term and long-term consequences of Brexit on four segments of competition policy in the UK and the EU: 1) Mergers \& Acquisitions (M\&A) policy; 2) Antitrust Policy; 3) Anti-cartel Policy; and 4) State Aid Control Policy. The final part discusses the future development of the UK competition law as related to the EU policy.

\section{Historical development of competition law in the EU and the UK}

\subsection{Historical development of competition law in the EU}

The foundations of the EU competition law can be found in the famous Schuman Declaration, ${ }^{3}$ named after the then French Minister of Foreign Affairs, Robert Schuman. From a legal point of view, the creation of the European Coal and Steel Community led to the need to create a supranational body tasked with regulating trade in the single market severely affected by trade barriers and cartels (Hudson, 2016: 1). This need was further strengthened by establishing the European Economic Community (EEC) in 1957. The abolishment of trade barriers and tariffs alone could not lead to the development of competition, but it was a step in the right direction. Historically speaking, we could say that the late 1950s and early 1960s were the first phase in the development of the EU competition law, marked by the efforts of the founding states of the European Community to delegate all powers in the field of competition law to a supranational body. The most important regulation from this period is Regulation 17/62 which establishes the idea of free competition in Europe. ${ }^{4}$

The second phase in the development of EU competition law is related to the period of the mid-1980s when European companies began to grow stronger and more often resorted to illicit methods of strengthening their market presence. In

3 European Union. The Schuman Declaration - 9 May 1950. Retrieved 13.3.2021 from https:// europa.eu/european-union/about-eu/symbols/europe-day/schuman-declaration_en

4 EUR-Lex. EEC Council: Regulation No 17: First Regulation implementing Articles 85 and 86 of the Treaty. Retrieved 3.3.2021 from https://eur-lex.europa.eu/legal-content/EN/ ALL/?uri=CELEX\%3A31962R0017 
that period, the attention of the competition policymakers was focused on the state aid, which should have been regulated in order not to violate one of the basic postulates of competition policy - the equality of market participants (Aydin, Thomas, 2012: 535). In this regard, one of the most important regulations in the area of competition law adopted in this period was the Merger Regulation (4064/1989). ${ }^{5}$

The third phase in the development of the EU competition law relates to the period of the 1990s. Namely, the increasingly intensive development of economic relations between the EU and its partners (predominantly, the USA) generated the need for a radical change in the way of combating illicit forms of market participants' behaviour. In 1995, the European Commission adopted a document titled White paper on damages actions for breach of the EC antitrust rules, ${ }^{6}$ giving the European Commission the power to focus on major cases of distortion of competition, while minor cases had to be dealt with at the member state level.

When it comes to specific cases of sanctioning companies that violate the rules on free competition, it is worth mentioning the so-called "truck cartel". In July 2016, the European Commission fined truck producers MAN, Volvo/Renault, Daimler, Iveco, and DAF a total of 2.93 billion Euros for forming a cartel and fixing truck prices over a period of fourteen years.

\subsection{Historical development of competition law in the UK}

Competition law has existed in the UK in various forms for several centuries. However, UK competition law (regulated by legal acts) began to develop only after World War II. The first legislative act in the field of competition law was the Monopolies and Restrictive Practices (Inquiry and Control) Act, adopted in 1948 (Scott, 2009: 6). This Act was the complete opposite of today's understanding of the concept of competition law. Namely, in the post-war economy, the UK controlled prices and was the only regulator of market activities. The state cartelization of the economy, carried out on the basis of this act, was actually aimed at state control of powerful capitalists in the private sector, and intensified control should have been exercised over their activities in the postwar period (Lever, 2009: 5).

5 EUR-Lex. Council Regulation (EEC) No 4064/89 of 21 December 1989 on the control of concentrations between undertakings. Retrieved 3.3.2021 from https://eur-lex.europa.eu/ legal-content/en/TXT/?uri=CELEX:31989R4064.

6 Commission of the European Communities. White Paper on Damages Actions For Breach Of The Antitrust Rules. Retrieved 3.3.2021 from https://ec.europa.eu/competition/antitrust/ actionsdamages/files_white_paper/whitepaper_en.pdf

7 European Commission. Antitrust/Cartel Cases. Retrieved 4.3.2021 from https://ec.europa. eu/competition/elojade/isef/case_details.cfm?proc_code=1_39824 
It was logical to expect that the UK, after joining the EEC in 1975, would harmonize its competition policy with the EEC competition policy. However, during the term of office of Prime Minister Margaret Thatcher, the UK competition policy distanced from the one advocated and implemented by EEC. The UK advocated a tough stance on the market as the most efficient way of allocating social resources and regulating the flow of economic activities. The privatization of enterprises, the liberalization of economic activities, and the increasing deprivation of the state's competence to monitor economic activities became a trademark of the UK competition policy in that period (Scott, 2009: 2). As the 1948 Act gave too much discretionary power to the state, the policymakers in the UK began to realize that the liberalization of the market and empowering competition in the long term could benefit both market participants and the state itself.

A new act in the field of competition law was passed in 1956, titled the Restrictive Trade Practices Act. The essence of this Act was the increased control of restrictive agreements and practices by the state (Richardson, 1967: 350 ). Certainly, control of restrictive agreements itself is a measure ultimately aimed at encouraging healthy competition in the market and preventing anti-competitive forms of companies' behaviour. However, the intention of the British legislator was that the state retains a certain degree of influence on economic entities, invoking the public interest as the supreme principle that should be protected. In practice, this meant that companies that had made agreements were obliged to submit them to the public registry, which, if deemed necessary, could forward any agreement to the specialized court for restrictive agreements. The final decision on whether the agreement could be considered restrictive was made by this court.

The subject matter of mergers and acquisitions of companies was regulated in 1965 by the legislative act titled the 1965 Monopolies and Mergers Act (Scott, 2009: 11). This Act authorized the Monopolies Commission to examine the existing and/or potential mergers and acquisitions of companies that would result in creating a monopoly (Goyder, 1965: 660). This authority was the forerunner of the Monopolies and Mergers Commission and, subsequently, the Competition Commission (Reader, 2015: 90). The ratio legis of this Act was the protection of the public interest that could be jeopardized by mergers and acquisitions.

The importance of the public interest, as the supreme principle that is supposed to protect against unwanted behaviour of companies, was further underlined by the Fair Trading Act 1973, which established the Office of Fair Trading to control 
all forms of competition disruptions, including the control of changes in market structure, business policy, and registrations of restrictive trade agreements. ${ }^{8}$

The legislative act that is currently in force in the UK is titled the Competition Act 1998 (Scott, 2009: 17). This Act was adopted to harmonize UK regulations regarding restrictive agreements and abuse of dominant position with the EU regulations, more specifically, with Article 101 (restriction of competition) and Article 102 (abuse of dominant position) of the Treaty on the Functioning of the European Union (former Articles 81 and 82 of the Treaty on the establishment of the European Community). Interestingly, this was the first legal act in the field of competition law to introduce fines on market participants who break the rules, instead of the previous written warnings (Cease \& Desist). Companies that violate the rules protecting free competition face a fine of up to $10 \%$ of their annual turnover. ${ }^{9}$ One of the heavier fines was $£ 63.6$ million, which was imposed on construction companies in England engaged in illegal anti-competitive bidding in a large number of tenders, mainly in the form of "covered prices" (The Institute of Risk Management \& Competition and Markets Authority, 2014).

Another legislative act that regulates the field of competition law in the UK was passed in 2002, titled the Enterprise Act 2002. Under this Act, the competent minister is given the authority to intervene in cases of mergers and acquisitions of companies that could more seriously violate the public interest defined by law. Although the legislator intended to give the executive branch greater discretionary powers in the field of competition law, in practice, the views of the Competition and Markets Authority were respected by the competent minister. ${ }^{10}$

\section{Consequences of Brexit on the M\&A policy in the EU and the UK}

\subsection{Consequences of Brexit on the M\&A policy in the $E U$}

The only short-term consequence of Brexit on the Mergers \& Acquisitions (M\&A) policy in the EU relates to the business transactions commenced before Brexit, which have not been completed yet. Namely, it is to be expected that the ongoing procedures will take time to be finished and that the regulatory framework that was in force before Brexit will continue to be in force until the completion of the merger and acquisition proceedings.

8 UK Parliament. Thirty-Seventh Report of the Committee of Public Accounts: The Office of Fair Trading: Protecting the Consumer From Unfair Trading Practices. Retrieved 1.4.2021 from https://publications.parliament.uk/pa/cm199900/cmselect/cmpubacc/501/50103.htm

9 Government of the United Kingdom. Avoid and report anti-competitive activity. Retrieved 1.4.2021 from https://www.gov.uk/cartels-price-fixing

10 The National Archives. Art. 132 of Enterprise Act 2002 (repealed). Retrieved 1.4.2021 from legislation.gov.uk 
An important long-term consequence of Brexit on the M\&A policy in the EU relates to the choice of applicable law and jurisdiction in the case of disputes related to the M\&A process. Namely, it should be borne in mind that the EU does not have a legally binding regulatory framework regarding the choice of applicable law and jurisdiction for international cases of mergers and acquisitions, thus, all such transactions are governed by the law of the state chosen by the parties to the agreement.

In business practice, the contracting parties generally chose the UK law as the applicable law for resolving possible disputes arising from the contractual relationship, and the English courts as the courts competent for resolving disputes. However, in M\&A cases that are not related to the UK, it should not be expected that the parties will choose UK law as the applicable law for resolving disputes or the jurisdiction of UK courts. On the other hand, as UK courts will no longer be bound by the case law of the EU Court of Justice, uncertainty should be expected in terms of the mutual recognition of court decisions between the UK and EU Member States (Loyens \& Loeff, 2016).

\subsection{Consequences of Brexit on the $M \& A$ policy in the $U K$}

The UK's withdrawal from the EU membership will undoubtedly have significant consequences on the M\&A policy of companies in the UK. Leaving the European single market and the UK's withdrawal from trade agreements will bring a great deal of uncertainty to the business of British companies. Differences in the regulatory framework of conducting business activities in the UK and the EU will bring certain difficulties for British companies in terms of obtaining permits for performing mergers and acquisitions with companies based in an EU member state. In this regard, it is important to note that British companies that have valid contractual relations with EU business partners will have to conduct a detailed analysis (due diligence) of concluded agreements and propose changes to their partners, conditioned by the changed regulatory framework of relations between the UK and the EU (Luther Rechtsanwaltsgesellschaft mbH, 2016).

When it comes to long-term consequences, the most important change will happen at the regulatory level. Namely, the European Merger Regulation 139/2004, which applies to all EU member states and based on which the European Commission has received the exclusive authority to control mergers of companies, will no longer apply to mergers involving companies from the UK..$^{11}$ The cessation of the application of regulations in the UK also means the formal legal cessation of

11 Buren. Brexit \& M\&A: impacts for targets with UK activities and for UK buyers. Retrieved 8.3.2021 from https://www.burenlegal.com/en/news/brexit-ma-impacts-targets-ukactivities-and-uk-buyers 
EU competencies in the field of competition law. The so-called "one-stop-shop" policy, which was applied in the process of merger control and which implied the authority of the European Commission to control the merger of companies on the UK market when there is a suspected distortion of free competition, will no longer apply to the UK. The British Competition \& Markets Authority will no longer carry out parallel merger control proceedings in cooperation with the European Commission but will have exclusive competence in this area. ${ }^{12}$ In terms of competition law, independence in policy-making (including competition policy), which was the guiding idea for withdrawing from the EU membership, will not bring much benefit to the UK in the long run. The complex mechanism of control of mergers and acquisitions of British companies with the EU companies, conditioned by the differences between the legal systems to which the UK and EU member states belong (i.e. the Anglo-Saxon and European-Continental legal systems), will create the need for cooperation between the Competition and Markets Authority and the European Commission. Of course, the level of cooperation between these two institutions will not be at the level it was when the UK was a full member of the EU, but the differences between the legal systems will inevitably lead to the need to exchange information in the process of merger and acquisition control.

In the field of protection of the public interest in cases of mergers and acquisitions, certain changes should be expected. Namely, Art. 21 of the European Union Merger Regulation No. 139/2004 empowers EU member states to apply measures within the exclusive competence of the European Commission, which protects competition from illegal mergers and acquisitions. Although there are certain elements of the term "public interest" common to the legal systems of all EU member states (for example, national security or media freedom), this term has additional elements in the UK, such as the stability of the financial system (Competition \& Markets Authority, 2016). In this regard, one can expect an increased influence of the executive power on the control of mergers and acquisitions of companies from the UK with companies from the EU, while calling for the defense of the "public interest" principle.

\section{Consequences of Brexit on antitrust policy in the EU and the UK}

\subsection{Consequences of Brexit on antitrust policy in the $\mathrm{EU}$}

When it comes to short-term consequences of Brexit, it should be expected that the EU law will be applied to all forms of monopolistic behavior occurring in the UK, which could negatively affect competition in the EU (Girardet, Saha, Meyer,

12 Bird \& Bird. The functions of the CMA post Brexit. Retrieved 11.4.2021 from https:// www.twobirds.com/en/news/articles/2020/uk/the-functions-of-the-cma-post-brexit 
2020: 5). The fact that the EU will treat the UK as a so-called "third-world country" will not affect the right of competition authorities in the EU to conduct proceedings and impose sanctions against companies which adversely affect free competition in the EU market through their illicit practices.

An important long-term consequence of Brexit is the loss of the European Commission's authority to conduct unannounced inspections ("dawn raid") at the company's headquarters in case of suspicion of monopolistic behavior. The European Commission will have to establish close cooperation with the Competition and Markets Agency to obtain the evidence necessary to conduct investigations against British companies that violate Articles 101 and 102 of the Treaty on the Functioning of the EU, which negatively affects free trade in the EU (Nourry, Chandralekha, 2018: 3).

\subsection{Consequences of Brexit on antitrust policy in the $U K$}

Given the UK's break with positive EU law and tradition, it should be expected that the UK will eventually adopt a new approach to competition policy, unencumbered by the obligation to comply with EU rules and contribute to preserving and strengthening single market principles. However, in the short term, one should not expect a drastic divergence from the EU competition law. Existing contractual relations between British and EU companies will make it necessary to respect the regulatory framework that existed between the UK and the EU before Brexit.

Section 60 of the UK 1998 Competition Act contains an obligation for British courts and regulators to comply with EU law. ${ }^{13}$ This obligation is important for British companies as it brings certainty to their business conduct in terms of compliance of their contracts and business decisions with business practices and EU regulations. In the spirit of preserving the economic interests of British companies that have contractual relations with EU partners, one possible shortterm solution is to change this section, by imposing an obligation on courts and regulators in the UK to "take into consideration" the EU law instead of the obligation to bring their decisions and procedures in each case in line with the EU law (Jones, 2017: 11). Namely, Section 60A will release the British courts from the obligation to interpret the UK competition law consistently with the

13 The provisions of Section 60 impose an obligation on British courts and the regulator to interpret the provisions prohibiting illicit conduct of market participants, contained in other parts of this Act, as closely as possible to Art. 101 and Art. 102 of the Treaty on the Functioning of the European Union. These articles relate to the prohibition of restrictive agreements and the abuse of a dominant position by companies. 
EU competition law. ${ }^{14}$ This change may seem to have short-term consequences on the EU antitrust policy, motivated by the UK's efforts to become independent of the EU as soon as possible (on the one hand) and by the necessity to protect the business interests of British companies (on the other hand). Yet, in practice, this change will mark a gradual divergence of the UK from the EU in the field of competition law.

The main issue that the UK Government will deal with in the years after Brexit is the amendment of the current Competition Act 1998. The ratio legis of all EU legal regulations in the field of competition law is the protection and promotion of the common market, as a trademark of united Europe. However, as the UK is no longer a member of the EU, the question arises whether and to what extent the current UK legislation will be amended, given that the UK is no longer formally part of the common market and has no obligation to adapt its competition law to the need of developing sound competition in the EU market. It should also be borne in mind that all decisions of the British regulator have been reviewed by the European Court of Justice, and it should not be expected that regulations that imply any control by the EU authorities will be applied in the UK (Jones, 2017: 11). The possibility of referring questions to the European Court of Justice concerning the interpretation of EU regulations was of great importance for the UK in harmonizing the interpretation of EU regulations. Given the cessation of this practice in the future, it is realistic to expect that the UK competition law and EU competition law will drift apart.

Another long-term consequence of Brexit relates to the UK's withdrawal from membership in the European Competition Network. ${ }^{15}$ The UK has benefited from membership in this organization in terms of successful cooperation with the national authorities of the EU member states in fighting illicit behavior of market participants (Dunne, 2017: 2).

Given the strong economic ties between British and EU companies, one should not expect a drastic change in the UK's approach to competition policy in the coming years. Simply put, the necessary orientation of the UK towards the EU, as the geographically closest and largest market in terms of population, will bring about a certain degree of cooperation between the authorities in charge of competition protection, which will be beneficial to companies "on both sides of the English Channel“.

14 The UK National Achives. Part 2: Amendment of the Competition Act 1998, Art. 23 of The Competition (Amendment, etc.) (EU Exit) Regulations 2019. Retrieved 29.3.2021 from https:// www.legislation.gov.uk/uksi/2019/93/contents/made

15 This organization is an institutional form of cooperation between the European Commission and the national competition authorities of the EU member states in the field of combating illicit forms of behavior of market participants in the EU market. 


\section{Consequences of Brexit on the anti-cartel policy in the EU and the UK}

\subsection{Consequences of Brexit on the anti-cartel policy in the $\mathrm{EU}$}

The Agreement on the withdrawal of the United Kingdom of Great Britain and Northern Ireland from the European Union and the European Atomic Energy Community 2019/C 384 I/01 (hereinafter: Withdrawal Agreement) regulates the issue of the competence of EU authorities to conduct proceedings initiated before Brexit. For all proceedings on examining cartel agreements of the UK companies which the European Commission has commenced before Brexit, Art. 92 (par. 3, item b) of the Withdrawal Agreement provides for further EC jurisdiction until the completion of these proceedings. ${ }^{16}$ It is important to point out that the European Commission will be competent only in cases of cartel agreements which, although concluded and implemented on the territory of the UK, distort competition on the EU market.

The most significant long-term consequence relates to the loss of competence of the European Commission to examine cartel agreements that result in distortions of competition exclusively in the territory of the UK (Luther Rechtsanwaltsgesellschaft $\mathrm{mbH}, 2016$ ).

EU companies planning to enter into agreements that can be classified as cartels must keep in mind that the violation of the positive legal regulations of the UK results in the jurisdiction of the British Competition and Markets Agency, as well as British courts. This is very important because the UK belongs to the Anglo-Saxon legal system, the essence of which is the doctrine of case law. ${ }^{17}$ As the essence of the Continental legal system conflicts with the essence of the Anglo-Saxon legal system, EU companies will face greater uncertainty regarding the decision on a possible penalty for illicit forms of behavior.

\subsection{Consequences of Brexit on the anti-cartel policy in the UK}

An important short-term consequence of Brexit concerns the competencies of the Competition and Markets Authority which will be able, despite the primary competence of the European Commission, to participate in investigations of cartel agreements concluded before Brexit, which could disrupt free trade in

16 Eur-Lex. Agreement on the withdrawal of the United Kingdom of Great Britain and Northern Ireland from the European Union and the European Atomic Energy Community. Retrieved 1.4.2021 from https://eur-lex.europa.eu/legal-content/EN/TXT/?uri=CELEX\%3A12020W\%2FTXT 17 Wirtschaftskanzlei Heuking Kühn Lüer Wojtek. Beratungsthemen im Zusammenhang mit einem drohenden Brexit: Kartellrecht/Beihilferecht. Retrieved 26.3.2021 from https:// www.heuking.de/de/news-events/fachbeitraege/beratungsthemen-im-zusammenhangmit-einem-drohenden-brexit-kartellrechtbeihilferecht.html 
the UK. ${ }^{18}$ Of course, once these proceedings are completed, the Competition and Markets Authority will be the sole authority to investigate cartels.

In the long run, the British Competition and Markets Authority will benefit from Brexit. As EU legal regulations in the field of competition law will no longer be applied in the UK, British courts will have greater freedom to develop legal principles independent of the existing principles contained in the EU competition law. This will result in an easier inter pretation of the regulations by the Competition and Markets Authority when dealing with cartel cases.

Probably the most important long-term consequence of Brexit is procedural. Given that the UK is no longer a member of the European Network of Competition Authorities, one should expect parallel proceedings conducted by the British Competition and Markets Authority, on the one hand, and the European Commission and a member of the European Network of Competition Authorities (national competition authorities of EU Member States), on the other hand. In practice, this means that conducting parallel proceedings against the same party would lead to imposing multiple penalties. ${ }^{19}$

When it comes to the control of agreements between companies that could distort competition, i.e. free trade in the EU, the European Merger Regulation is the legal basis for the supervision of such agreements by the European Commission, whose decisions have stronger legal force than the decisions of national competition authorities. However, as the UK is no longer an EU member, the competence of the European Commission in this area ceases and the British regulator will exclusively apply positive British legislation to the examination of cartel cases involving companies from the UK. ${ }^{20}$

One important change in the field of procedural law should also be expected. Considering that the British courts are no longer bound by the decisions of the European Commission regarding the cartel agreements, a party aggrieved by such an agreement will not be able to base a claim for damages on the decision

18 White \& Case. Changing Roles: the CMA during the Transition Period. Retrieved 25.3.2021 from https://www.whitecase.com/publications/alert/changing-roles-cma-during-transitionperiod-and-beyond

19 Gleiss Lutz. Brexit: EU-Kartellrecht ohne Großbritannien. Retrieved 25.3.2021 from https://www.gleisslutz-brexit.com/pdf/Brexit_\%20EU-Kartellrecht\%20ohne\%20 Gro\%C3\%9Fbritannien.pdf

20 Friedrich Graf von Westphalen - Rechtsanwälte. Brexit und Kartellrecht: Vorsicht bei wettbewerbsbeschränkenden Vereinbarungen mit UK-Bezug. Retrieved 25.3.2021 from https:// www.fgvw.de/brexit/brexit-und-kartellrecht-vorsicht-bei-wettbewerbsbeschraenkendenvereinbarungen 
of the European Commission but will have to engage in the process of proving cartel agreement and damage. ${ }^{21}$

\section{Consequences of Brexit on state aid policy in the EU and the UK}

\subsection{Consequences of Brexit on state aid policy in the $E U$}

State aid policy is the field where there has been the most controversy between the EU and the UK during the negotiations on the signing of the Withdrawal Agreement. As with other forms of competition policy, the main short-term consequence of Brexit will be the question of the competence of the European Commission in state aid control proceedings. Namely, the European Commission will remain responsible for the control of state aid granted by the UK, and initiated before Brexit. The European Commission will also be responsible for initiating new state aid control proceedings for the state aid granted by the UK before the expiry of the so-called transition period (which lasted until 31 December 2020), but only if it initiates the proceedings within four years from the end of the transition period. All decisions made by the European Commission in these proceedings will be binding on the UK. The European Commission will be able to initiate proceedings against British companies before the European Court of Justice in the event of non-compliance with its decisions within a period of four years after the end of the transitional period or the date of the decision, whichever is later. All these consequences are described in the Notice to Stakeholders - Withdrawal of the United Kingdom and EU Rules in the Field of State Aid, a document issued by the European Commission in January 2021. ${ }^{22}$

The EU state aid control policy is composed of two components. The primary purpose of this policy is to protect trade between the member states from the negative impact of measures adopted by the member states, aimed at providing financial assistance to certain companies. Of course, the essence of state aid control is the protection of the market economy, embodied in the single market, which is the second component of state aid control policy (Schonberg, 2017: 51).

In the long run, one procedural legal consequence of Brexit should be expected. EU law in the field of state aid control will no longer be applied on the territory of the UK, and European companies will be denied the opportunity to address

21 Legal Tribune Online. Der Brexit und das Wettbewerbsrecht. Nur Nachteile - und zwar für alle. Retrieved 26.3.2021 from https://www.lto.de/recht/kanzleien-unternehmen/k/ brexit-abkommen-wettbewerbsrecht-beihilfenrecht-unternehmen-kartellverfahren/

22 European Commission - Directorate-general competition. Notice to stakeholders Withdrawal of the United Kingdom and EU rules in the field of State Aid. Retrieved 28.3.2021 from https://ec.europa.eu/info/sites/info/files/notice-stakeholders-brexit-state-aid_en.pdf 
the European Commission if they believe that state aid favors their competitors in the UK in any way. The only legally available remedy will be the possibility of addressing British courts directly, which will introduce uncertainty into the business of European companies, considering the still insufficiently clear future regulatory framework in this field in the UK. ${ }^{23}$

\subsection{Consequences of Brexit on state aid control policy in the UK}

After Brexit, there will be no formal legal framework for state aid control policy in the UK. The adoption of a new legislative act in this field might be expected in the future. Until it adopts a new legal act, the UK will be subject to the World Trade Organization (WTO) state aid control regime. It is also important to note that the UK will be obliged to act upon the decisions of the European Commission and the judgments of the EU Court of Justice in the proceedings of control of state aid granted by the EU before Brexit. ${ }^{24}$

The UK's withdrawal from the EU membership could in the long run bring some changes to the existing state aid control policy. A new law in the area of state aid control should be expected, which would set the UK on a clear course in pursuing this policy. However, given the complexity of this matter, it is uncertain when the new regulations will be adopted.

The change that can be expected is the establishment of an independent authority that will be in charge of state aid control. This authority should be free from any external influence ${ }^{25}$ The solution could be found in the existing Competition and Markets Authority, which has never dealt with the state aid control; it is independent in its work and could be a good candidate for performing responsible functions in the field of state aid control.

\section{Conclusion}

Although Brexit is a major milestone in the development of the EU, it will undoubtedly have greater consequences for competition law in the UK than in the

23 White \& Case. State aid and the Brexit Trade Agreement: What's new, what's not, and what's next. Retrieved 29.3.2021 from https://www.whitecase.com/publications/alert/ state-aid-and-brexit-trade-agreement-whats-new-whats-not-and-whats-next

24 Pinsent Masons. State aid laws to be revoked in the UK. Retrieved 2.4.2021 from https:// www.pinsentmasons.com/out-law/news/state-aid-laws-to-be-revoked-in-the-uk

25 Official Journal of the European Union. Part Two, Heading One, Title XI, Article 3.9 of Trade And Cooperation Agreement Between The European Union And The European Atomic Energy Community, Of The One Part, And The United Kingdom Of Great Britain And Northern Ireland, Of The Other Part. Retrieved 31.3.2021 from https://eur-lex.europa.eu/legal content/EN/ TXT/?qid=1580206007232\&uri=CELEX\%3A12019W/TXT\%2802\%29 
EU. In the short term, one should not expect a drastic change in the regulatory framework of the UK competition law. It is certain that already commenced proceedings against British companies infringing the rules on free competition will be completed by the European Commission. Retaining the competencies of the European Commission for conducting already initiated proceedings in the area of competition law will be a common feature of the short-term consequences of Brexit.

In the long run, however, UK companies will be severely affected by the new reality. The break with the EU acquis and the loss of access to the common market will lead to the reorganization of companies' business policies and redefining their approach to competition with EU companies. Creating a new concept of state aid policy will probably be one of the biggest challenges for the British Government in the years to come. The legal vacuum created after Brexit is not sustainable in the long run. Thus, policymakers will have to figure out a way to financially support the British companies, while taking care not to negatively affect the competitiveness of the British economy. Moreover, the fact that the UK is no longer a member of the European Network of Competition Authorities will be an aggravating factor for the UK in its efforts to establish closer cooperation with the national competition authorities of the EU Member States.

Although the European Union has lost one of the economically and politically most powerful members, the EU will be less affected by Brexit than the UK. Simply put, the EU companies still have access to the common market, and their competitiveness in the EU market will be far greater than the competitiveness of the UK companies. Unlike in the UK, competition law regulations will remain unchanged in the EU. The European Commission will retain jurisdiction to conduct proceedings against British companies if the effects of their actions and decisions have negative consequences on free trade in the EU single market.

\section{References}

Aydin, U., Thomas, P.K. (2012). The Challenges and Trajectories of EU Competition Policy in the Twenty-first Century. Journal of European Integration. 34 (6). 531-547

Competition \& Markets Authority. (2016). Public Interest Regimes in the European Union - differences and similarities in approach, Final Report of the EU Merger Working Group 10 March 2016

Cseres, K. (2010). Comparing Laws in the Enforcement of EU and National Competition Laws. European Journal of Legal Studies. 3 (1). 7-44 
Dunne, N. (2017). Competition Law and Policy after Brexit. Department of Law, London School of Economics and Political Science. LSE Law Policy Briefing Series Brexit Special 4.1-4

Girardet, P., Saha, R., Meyer, P. Brexit - How Will Antitrust Cases and Mergers be Impacted? (2020), Willkie Farr \& Gallaghier (UK) LLP. Available at: https://www. willkie.com/-/media/files/publications/2020/01/brexithowwillantitrustcasesandmergersbeimpacted.pdf

Goyder, D.G. (1965). Public Control of Mergers. Modern Law Review. 28 (6). 654-674

Hudson, N. (2016). The European Coal and Steel Community: the Path Towards European Integration. Portland State University, University Honors Theses. Paper 276.1-41. Available at: https://pdxscholar.library.pdx.edu/cgi/viewcontent.cg i?article $=1304 \&$ context=honorstheses

Jones, A. (2017). Brexit: Implications for UK Competition Law. King's College London Dickson Poon School of Law. Legal Studies Research Paper Series: Paper No. 2017-21. 1- 21. Available at: https://bit.ly/3tuB06p

Lever, J. (1999). The Development of British Competition Law: a Complete Overhaul and Harmonization. Wissenschaftszentrum Berlin für Sozialforschung (WZB), Berlin. WZB Discussion Paper, no. FS IV 99-4.1-39

Loyens \& Loeff. (2016). Brexit: what might change Corporate / M \& A

Luther Rechtsanwaltsgesellschaft mbH. (2016). Newsletter: Mergers \& Acquisitions 4. Quartal 2016. Brexit: Impact on M\&A

Nourry, A., Chandralekha, G. Dawn Raids - Expect the Unexpected. (2018). Clifford Chance LLP. Available at: https://www.cliffordchance.com/content/ dam/cliffordchance/PDFDocuments/dawn_raids_expect_the_unexpected.pdf

Reader, D . (2015). Revisiting the Role of Public Interest in Merger Control, Thesis submitted for the degree of Doctor of Philosophy. University of East Anglia UEA Law School. Available at: https://ueaeprints.uea.ac.uk/id/eprint/68329/1/David_Reader_-_PhD_Document_(Final).pdf

Richardson, J.J. (1967). The Making Of The Restrictive Trade Practices Act 1956 - A Case Study Of The Policy Process In Britain. Parliamentary Affairs. 20 (4). 350374

Schonberg, M. (2017). Continuity or change? State aid control in a post-Brexit United Kingdom. Competition Law Journal. 16 (1). 1-62 
Scott, A. (2009). The Evolution of Competition Law and Policy in the United Kingdom. London School of Economics and Political Science Law Department. LSE Law, Society and Economy Working Papers 9/2009. 1-27. Available at: http:// eprints.lse.ac.uk/24564/1/WPS2009-09_Scott.pdf

The Institute of Risk Management \& Competition and Markets Authority. (2014). Competition Law Risk - A Short Guide. Available at: https://assets. publishing.service.gov.uk/government/uploads/system/uploads/attachment_ data/file/372555/CMA_Risk_Guide.pdf

\section{Electronic sources}

Buren. Brexit \& M\&A: impacts for targets with UK activities and for UK buyers. Retrieved 8.3.2021 from https://www.burenlegal.com/en/news/brexit-maimpacts-targets-uk-activities-and-uk-buyers

Commission of the European Communities. White paper on Damages actions for breach of the EC antitrust rules. Retrieved 3.3.2021 from https://ec.europa.eu/ competition/antitrust/actionsdamages/files_white_paper/whitepaper_en.pdf Encyclopedia Britannica. Treaty of Rome. Retrieved 13.2.2021. from https:// www.britannica.com/event/Treaty-of-Rome

EUR-Lex. Agreement on the withdrawal of the United Kingdom of Great Britain and Northern Ireland from the European Union and the European Atomic Energy Community. Retrieved 1.4.2021 from https://eur-lex.europa.eu/legal-content/ EN/TXT/?uri=CELEX\%3A12020W\%2FTXT

EUR-Lex. Council Regulation (EEC) No 4064/89 of 21 December 1989 on the control of concentrations between undertakings. Retrieved 3.3.2021 from https://eur-lex. europa.eu/legal-content/en/TXT/?uri=CELEX:31989R4064.

EUR-Lex. Council Regulation (EEC) No 4064/89 of 21 December 1989 on the control of concentrations between undertakings. Retrieved 3.3.2021 from https://eur-lex. europa.eu/legal-content/en/TXT/?uri=CELEX:31989R4064.

EUR-Lex. EEC Council: Regulation No 17: First Regulation implementing Articles 85 and 86 of the Treaty. Retrieved 3.3.2021 from https://eur-lex.europa.eu/legalcontent/EN/ALL/?uri=CELEX\%3A31962R0017

EUR-Lex. EEC Council: Regulation No 17: First Regulation implementing Articles 85 and 86 of the Treaty. Retrieved 3.3.2021 from https://eur-lex.europa.eu/legalcontent/EN/ALL/?uri=CELEX\%3A31962R0017

European Commission - Directorate-general competition. Notice to stakeholders - Withdrawal of the United Kingdom and EU rules in the field of State Aid. Retrieved 
28.3.2021 from https://ec.europa.eu/info/sites/info/files/notice-stakeholdersbrexit-state-aid_en.pdf

European Commission. The Maastricht Treaty: an impetus for the cohesion policy. Retrieved 9.2.2021 from https://ec.europa.eu/regional_policy/en/newsroom/ news/2016/12/12-09-2016-the-maastricht-treaty-an-impetus-for-the-cohesionpolicy\#: :text $=$ The $\% 20$ treaty $\% 20$ brought $\% 20$ the $\% 20$ first, the $\% 20$ Economic\% 20and\% 20Monetary\% 20Union.

European Commission. Antitrust / Cartel Cases. Retrieved 4.3.2021 from https:// ec.europa.eu/competition/elojade/isef/case_details.cfm?proc_code=1_39824

European Union. The Schuman Declaration - 9 May 1950. Retrieved 13.3.2021 from https://europa.eu/european-union/about-eu/symbols/europe-day/schuman-declaration_en

Friedrich Graf von Westphalen - Rechtsanwälte. Brexit und Kartellrecht: Vorsicht bei wettbewerbsbeschränkenden Vereinbarungen mit UK-Bezug. Retrieved 25.3.2021 from https://www.fgvw.de/brexit/brexit-und-kartellrecht-vorsichtbei-wettbewerbsbeschraenkenden-vereinbarungen

Gleiss Lutz. Brexit: EU-Kartellrecht ohne Großbritannien. Retrieved 25.3.2021 from https://www.gleisslutz-brexit.com/pdf/Brexit_\%20EU-Kartellrecht\%20 ohne $\% 20$ Gro\%C3\%9Fbritannien.pdf

Government of the United Kingdom. Avoid and report anti-competitive activity. Retrieved 1.4.2021 from https://www.gov.uk/cartels-price-fixing

Legal Tribune Online. Der Brexit und das Wettbewerbsrecht. Nur Nachteile - und zwar für alle. Retrieved 26.3.2021 from https://www.lto.de/recht/kanzleienunternehmen/k/brexit-abkommen-wettbewerbsrecht-beihilfenrecht-unternehmen-kartellverfahren/

Official Journal of the European Union. Part Two, Heading One, Title XI, Article 3.9 of Trade and Cooperation Agreement between the European Union and the European Atomic Energy Community, of the one part, and the United Kingdom of Great Britain and Northern Ireland, of the other part. Retrieved 31.3.2021 from https://eur-lex.europa.eu/legal-content/EN/TXT/?qid=1580206007232\&uri= CELEX\%3A12019W/TXT\%2802\%29

Pinsent Masons. State aid laws to be revoked in the UK. Retrieved 2.4.2021 from https://www.pinsentmasons.com/out-law/news/state-aid-laws-to-be-revokedin-the-uk

The National Archives, Art. 132 of Enterprise Act 2002 (repealed). Retrieved 1.4.2021 from legislation.gov.uk 
The National Archives. Part 2 Amendment of the Competition Act 1998 Art. 23 of The Competition (Amendment etc.) (EU Exit) Regulations 2019. Retrieved 29.3.2021 from https: //www.legislation.gov.uk/uksi/2019/93/contents/ made

UK Parliament. Thirty-Seventh Report of the Committee of Public Accounts: The Office of Fair Trading: Protecting the Consumer From Unfair Trading Practices. Retrieved 1.4.2021 from https://publications.parliament.uk/pa/cm199900/ cmselect/cmpubacc/501/50103.htm

White \& Case. Changing Roles: the CMA during the Transition Period. Retrieved 25.3.2021 from https://www.whitecase.com/publications/alert/changing-rolescma-during-transition-period-and-beyond

White \& Case. State aid and the Brexit Trade Agreement: What's new, what's not, and what's next. Retrieved 29.3.2021 from https://www.whitecase.com/ publications/alert/state-aid-and-brexit-trade-agreement-whats-new-whatsnot-and-whats-next

Wirtschaftskanzlei Heuking Kühn Lüer Wojtek. Beratungsthemen im Zusammenhang mit einem drohenden Brexit: Kartellrecht/Beihilferecht. Retrieved 26.3.2021 from https://www.heuking.de/de/news-events/fachbeitraege/beratungsthemen-im-zusammenhang-mit-einem-drohenden-brexit-kartellrechtbeihilferecht. html 


\author{
Др Александар Мојашевић, \\ Ванредни професор, \\ Правни факултет Универзитета у Нишу \\ Стефбан Стефановић, \\ Докторанд, \\ Правни факултет Универзитета у Нишу
}

\title{
ПОСЛЕДИЦЕ БРЕГЗИТА ПО ПРАВО И ПОЛИТИКУ КОНКУРЕНЦИЈЕ УЈЕДИЊЕНОГ КРАЉЕВСТВА И ЕВРОПСКЕ УНИЈЕ
}

\begin{abstract}
Резиме
Предмет овог рада јесу краткорочне и дугорочне последище Брегзита историјског догађаја и прекретнице у развоју Европске уније (ЕУ), по право и политику конкуренције Уједињеног Краљевства (УК) и ЕУ. Упоредна анализа историјског развоја правног регулисања конкуренције у УК и ЕУ, с приказом релевантних случајева из праксе органа за заштиту конкуренције, дата је на почетку рада. Посебан акценат стављен је на одлуке Европске комисије у вези с политиком борбе против картела. Укојој мери ће Брегзит утицати на политику спајања и припајања компанија, антимонополску политику, политику борбе против картела и политику државне помоћи у УК и ЕУ, теме су које су у раду обрађене. Централно питање односи се на меру утицаја Брегзита на промену пословног амбијента у УК и ЕУ и реперкусија које ће та промена имати на право конкуренције. На крају су дата закључна разматрања у погледу правца будућег развоја права конкуренције УК, односно да ли ће и у којој мери право УК бити усаглашено с правом конкуренције и судском праксом ЕУ у тој области, или ће доћи до радикалног заокрета ка усвајању потпуно новог концепта политике и права конкуренције.
\end{abstract}

Кључне речи: Брегзит, право конкуренције УК, право конкуренције ЕУ, краткорочне последице, дугорочне последице. 